\title{
The effects of social capital on team performance: A study of RD departments in Uzbekistan
}

\author{
Akmal Hudaykulov, Xu Hongyi \\ School of Management Science, Wuhan University of Technology, China
}

\begin{abstract}
The aim of the investigation was to explain impact of various dimensions of social capital on cooperation. In the attempt we constructed a research model by utilizing social capital theory. Ultimately cooperation within research and development teams in textile industry in Uzbekistan was assessed. A survey method was applied and a questionnaire was developed and administered to. Structural Equation Modelling together with multiple regression was used to test the predictive value of our model on the sample of 170 Research and development department members. Findings suggest there is a large positive impact of social capital on cooperation. Therefore, the study confirms the value of social capital in explaining cooperation. The study helps managers and team members to better understand the importance of social capital generation on projects and in organizations. The developed concept can be used as a framework for facilitating cooperation for governments, research institutions, academic institutions and companies.
\end{abstract}

Key words: social capital theory, team cooperation, Uzbekistan, trust, reciprocity, social ties, identification

\section{INTRODUCTION}

In past decade researchers and experts in management field gave great amount of attention to social capital theory. In organization studies the concept of social capital is gaining currency too It demonstrates to be a powerful element explaining actors' relative accomplishment in a number of places of main concern to organizational scholars. Different interactions of individuals within a team and outside can bring favorable outcomes to organization. Social capital facilitates interunit resource exchange and product innovation (Gabbay and Zuckerman, 1998; ; Tsai and Ghoshal, 1998), the creation of intellectual capital (Hargadon and Sutton, 1997; Nahapiet and Ghoshal, 1998), and cross-functional team effectiveness (Rosenthal, 1996). Social capital reduces turnover rates (Krackhardt and Hanson, 1993) and it facilitates entrepreneurship (Chong and Gibbons, 1997) and the formation of start-up companies (Walker, Kogut and Shan, 1997). Furthermore, whom we know and how we communicate with them can shape our relations in life and work. For instance, social capital influences career success (Burt, 1992; Gabbay and Zuckerman, 1998;) and executive compensation (Belliveau, O'Reilly, and Wade, 1996;) It also helps workers find jobs (Granovetter, 1973, 1995; Lin and Dumin, 1996;) and creates a richer pool of recruits for firms (Fernandez, Castilla, and Moore, 2000).

Trust and reciprocity were found to nurture team cohesiveness and create positive atmosphere in teamwork. Social capital strengthens supplier relations (Asanuma, 1985; Dore, 1983;Gerlach, 1992; Helper, 1990;Smitka, 1991; Uzzi, 1997), regional production networks (Romo and Schwartz, 1995), and interfirm learning (Kraatz, 1998). Seeking to explain idea and support its use in organizational theory we try analyzing previous studies and constructing a framework of social capital and its influence on team cooperation in organization. This will show us benefits, risks, possibilities, theoretical and practical implications we can utilize in order to achieve organizational success. After 


\section{Akmal Hudaykulov, Xu Hongyi \\ The effects of social capital on team performance: A study of RD departments in Uzbekistan}

observing many organizations functioning in Uzbekistan textile industry, we found out that cooperation in R\&D teams was one the main reasons which has caused instability of company performance. Therefore, improving social ties and enhancing cooperation in teams can help R\&D teams and other department to fulfill organizational goals.

Jackman and Miller (1998) were the first to point out a divergence in the social capital literature between the original conception of Coleman (1988), in which a denser social network among strategic actors casts a longer shadow of the future; and the more popular notion of Putnam (1993), that participation in social organizations acculturates members to cooperative norms. We believe that social capital habituates cooperative behavior, thus creating potential for future interactions. Therefore, our study aims to evaluate the impact of social capital aspects on cooperation in Uzbekistan textile industry among R\&D workers. First, the theory of social capital is explained. Next the research model is constructed. We describe the methods applied and present the analysis from which useful findings were derived. Finally implications for the theory and practice are discussed followed by the conclusion.

\section{THEORETICAL BACKGROUND AND DEFINITION OF SOCIAL CAPITAL}

The expression social capital was in occasional use from about 1890, but only became widely used in the late 1990s. The current appearance of social capital concept changed the academic interest for an old debate in social science: the relationship between trust, social networks and the advance in modern industrial society. Social Capital Theory became popular through the integration of classical sociological theory with the description of an subtle form of capital. Social capital can just be engendered together thanks to the occurrence of groups and social networks, however it can be used among individuals and groups at the same time. Individuals can use social capital of their networks to accomplish private goals and groups can imply it in order to impose a certain set of norms or behaviors. In this sense, social capital is generated collectively but it can also be used individually, bridging the dichotomized approach 'communitarianism' versus 'individualism' (Ferragina, 2010)

Forms of social capital of Nahapiet and Ghoshal's framework are a subject of study that draws substantial interest. Authors proposed three main types of social capital which are cognitive social capital, structural social capital and relational social capital. Nahapiet and Ghoshal (1998) posit cognitive social capital that refers to "shared representations, interpretations, and systems of meaning among parties" that enable individuals within the network to make sense of information and to classify it into perceptual categories. It facilitates the exchange of information that allows individuals to share each other's thinking processes. Shared goals can motivate team members to share knowledge and cooperate with each other (Arnett and Badrinarayanan, 2005).

Leena and Pil (2006) defined that the structural social capital refers to the connecting among actors with whom and with what frequency they share information. The organization can be viewed as a social network. Social network theory defines society as built up of individuals in various forms, with weak and strength ties. A number of researches has confirmed that strong social ties provide firms with access and resources, such as knowledge to reduce costs (Bonner, Kim, and Cavusgil, 2005). Strong social ties allow the flow of valuable information or knowledge into the actors to behave proactively and innovatively regarding the firms (Luo, 2003; Walter, Auer and Ritter, 2006). This flow of knowledge may take the form of information and know how, skills, management capabilities, and market knowledge (Kale, Singe and Perlmutter, 2000), which can leverage to improve firm growth and overall firm performance (Bonner, Kim, and Cavusgil, 2005). The third dimension of social capital is relational. Tsai and Ghoshal (1998) asserted that shared vision, the key manifestations of cognitive social capital, might encourage the development of relational social capital. Social interaction ties may inspire trust and perceived trustworthy which represent the relational dimension (Krackhardt, 1992; Nelson, 1989). Tsai and Ghoshal defined the relational dimension of social capital as assets that are rooted in these relationships, such as trust and trustworthiness. Trust is a characteristic of an association, but trustworthiness is an element of an individual actor engaged in the affiliation (Barney and Hansen, 1994). The idea of cognitive social capital based on mental process that happens among thought, affect and action. We can 


\section{Akmal Hudaykulov, Xu Hongyi \\ The effects of social capital on team performance: A study of RD departments in Uzbekistan}

observe different schools of thought within the social cognitive theory including self-interest theory (Smith, 1776), social cognitive (Bandura, 1977,1986) that is helpful for understanding and predicting both group and individual behavior and recognizing the methods. Social capital can be understood roughly as the kindness that is stimulated by the fabric of social relations and that can be equipped to enable action - has primed the study of youth behavioral problems, community life, governance and democracy, and economic growth.

The fundamental insight escorting social capital study is that kindness that other people have towards us is precious resource. Social capital captures the trust, shared norms and values arising within informal social networks that affect expectations and behavior, thereby generating externalities for the members of a group (Durlauf and Fafchamps, 2004). That is, we consider social capital to encompass cognitive components (trust, norms, values) as well as structural components (social networks, voluntary associations, roles and rules). Therefore, it help predict social interactions particularly cooperation that is crucial to team performance. In our research however we focus on certain aspects of social capital, which we have identified as most conducive to cooperation within the context of our study. Next we present our research model and hypotheses.

\section{RESEARCH MODEL AND HYPOTHESIS}

\section{INSTRUMENTAL TIES AND EXPRESSIVE TIES}

Previous researchers have demonstrated that both instrumental ties and expressive ties can facilitate effective team cooperation. According to social network theory, social network ties are regarded as convenient conduits that facilitate exchange of information and mutual support within teams. People will both be more aware of and value to a greater extent the expertise and specialized knowledge of their egocentric networks of the team than people with whom they are less familiar (Borgatti and Cross, 2003). Ties serve as underlying mechanism through which two types of social network ties exert an impact on team cooperation. Within the cooperation context both instrumental and expressive ties can facilitate knowledge sharing directly (Lin, 2006) or through the mediating role of trust (Lin, 2007). Instrumental ties involve information and knowledge exchange and are conceived as conduits of work advice (Umphress et al., 2003). The expressive ties among team members can also release work-related information, with expressive ties characterized as more interactive and therefore as constituting a more effective approach for the transfer of tacit knowledge which revolve on cooperation. The knowledge sharing and interaction activities help members learn more about the content and depth of one another's knowledge and help to elaborate, refine and clarify members' perceptions of member-expertise associations that leads to cohesiveness of team cooperation (Lewis, 2004). Besides the knowledge map formation, close instrumental and expressive ties can also facilitate team members to know what kind of information and knowledge other team members need; which may also promote the specialization about knowledge allocation and processing within the cooperative teams. After the formation of such knowledge sharing, team members may then concentrate on and bear the obligation of developing their own expertise in order to refine their own job performance and enhance their personal specialization toward a cooperative setting. This leads to the following hypotheses:

H1a. Instrumental ties within teams are positively related to cooperation in teams. H1b. Expressive ties within teams are positively related to cooperation in teams.

\section{TRUST}

In exploratory study done by Jones and George (1998) trust is found to have implications towards team cooperation which means trust is a degree and can have direct implications on the type of interactions individuals pursue trust as a psychological construct which is the outcome of the interaction of people's values, attitudes, moods and emotions. Values of trust on desirable end states or behaviors that transcend specific situations, guide selection or evaluation of behaviors and events, and are ordered by 


\section{Akmal Hudaykulov, Xu Hongyi \\ The effects of social capital on team performance: A study of RD departments in Uzbekistan}

relative importance $\mathrm{n}$ team cooperation (Schwartz and Bilsky, 1987). Barber (1983) adds that Trust not only initiates shared values in team cooperation, it also serves to maintain and express the shared values that foster its emergence and, in turn, help create trust-based relationships. Many studies have shown that trust leads to team cooperation (Axelrod, 1984; Ekelund, 2002; Garbarino and Johnson, 1999; Morgan and Hunt, 1994; Mukherjee and Nath, 2003; Rodriguez and Wilson, 2002; Varamaki, 2001; Wetzels et al., 1998; Wong and Sohal, 2002; Ylimaz and Hunt, 2001). Trust can be reinforced through interpersonal cooperation (Morgan and Hunt, 1994) and ultimately enhance inter-organizational cooperation (Mavondo and Rodrigo, 2001). Similarly, research has shown that individuals who are trustworthy (or endorse values such as honesty) tend to view others as trustworthy (or as endorsing similar values fostering trust). Building trust is important to maintain cooperation among team members especially in which interdependence of team members are critical (Chakrabarty et al., 2007). The trust level among members is critical for common understanding, bonds and shared vision team. Shared vision in an organization can create the belief that the members won't harm each other, and this cooperation helps team members exchange their thoughts and resources toward common goals.

H2 Trust has a positive impact on cooperation

\section{IDENTIFICATION}

Identification has been studied in exchange theory (Cook and Emerson, 1978) and is recognized in psychology as one of the stronger relationship measures toward team cooperation (Ko, Price, and Mueller, 1997). While, Gundlach, Achrol, and Mentzer, (1995); Mavondo and Rodrigo, (2001); Morgan and Hunt, (1994) add that identification is a key factor in building long-term team cooperation. For team cooperation, identification is an important constituent because it demonstrates how success and strength can be achieved in cooperatives by sharing resources and decisions (Medina-Munoz and Garcia-Falcon, 2000). in review of literature learned that very experienced managers collaborated across businesses because they identified with the firm's overall strategic goals; in other words, they identified with the whole firm, and not only with their teams (Xuepan, 2012). They went beyond dyadic personal relationships and strove for the development of team spirit by initiating events (e.g., a ski weekend, drinks after work, etc. which ultimately stimulates cooperation). Identification enhances the perspectives aligned to understanding, reflection, and anticipate the other party's needs and intentions, as well as create a shared basis for cooperation. As a result, identification enabled interaction over a longer period, such as sharing an office on the same floor, and so on. Several social network studies underline the importance of identification when developing social capital toward cooperation of team members (Casciaro, 1998; Mehra, Kilduff, and Brass, 2001). We also observed that very experienced managers could identify the different social capital qualities and stages required in a team cooperation. Examples of this self-reflection include knowing one another and working together as a basic condition (contact), but equally importantly trusting one another's goodwill enough to refer a name (benevolence-based trust), as well as a shared vision to realize long-term collaboration (identification). Beyond this, very experienced managers not only used their strong social capital as an enabler of joint product/ market development, but also as a stepping stone to engage in new interpersonal links with the other teams. Thus, we hypothesis

H3 Identification has positive impact on cooperation.

\section{RECIPROCITY}

In the context of team cooperation, reciprocity leads to team commitment and creates incentives for organizations to share resources and know-how. A study by Baron and Markman (2000) showed that having willingness for positive reciprocity could be helpful for team cooperation processes between members and their networks implicitly contain reciprocal actions. Reciprocity has positive impact on cooperation of team members within organizations (Blau, 1964). According to Simmel, (1950) reciprocate tendencies to others' actions is a common feature of social life regardless of the social setting. Not surprisingly, research has consistently documented the presence of reciprocity in cooperation 


\section{Akmal Hudaykulov, Xu Hongyi \\ The effects of social capital on team performance: A study of RD departments in Uzbekistan}

of team networks (Molm et al., 2007). Social capital based on positive reciprocity might, therefore, be of importance in maintaining and developing cooperative relationships when team projects are not or only partially enforceable. Moreover, Cable and Shane (1997) propose that social capital in terms of positive reciprocity might be a key factor in the cooperation of team's ability to get access to venture capital or develop alliances with larger companies. Reciprocity is the practice of give and take and is crucial for the development and understanding of project teams toward a common goal. This cooperation of team members driven by reciprocity is based on norms of exchange in which individuals feel obligated to return favors (Mavondo and Rodrigo, 2001). Reciprocity is also a universal characteristic of human behavior (Goulder, 1960) that satisfies egoistic desires in team cooperation. Reciprocity is a gradual construct that can be established in way that it almost always follows the same predicted behavior, whereas sometimes it has only a minor impact. Reciprocity therefore also controls for perceived risk that co-operative partners bear with them. By reciprocating good deeds, individuals increase their chances of receiving future benefits. Thus, reciprocity channels egoistic impulses toward the maintenance of cooperation (Deckop et al., 2003). We posit that reciprocity plays a crucial role to build strong cooperation in teams because it necessitates immediate benefits but it also may involve expectations of future returns, although the initial returns may not be equal. Since literature has shown that reciprocity leads to team cooperation (Kumar, Scheer, and Steenkamp, 1995; Mavondo and Rodrigo, 2001), feelings of being treated well are likely to lead to good outcomes and have a self-reinforcing effect that creates beliefs the co-operative relationships will lead to positive future outcomes. Thus, we hypothesis that;

\section{RESEARCH METHODOLOGY}

A questionnaire instrument was developed and was distributed online to gather all the information necessary for answering the research questions. Existing multi-item scales accordingly adapted to fit the context of R\&D departments' work measured all the latent variables. The questionnaire includes series of questions and statements, requiring Likert scaled answers, designed to test the hypothesized relationships between variables of the model.

\section{MEASUREMENT DEVELOPMENT}

The questionnaire was designed by modifying scales used in prior studies in order to increase the validity of the measurement instrument. All the latent variables were operationalized and measured with items which were validated by other researchers.

To normalize the data, we adjusted the scale wording so all items were measured with a 7 point Likert scale with anchors being $1=$ strongly disagree, $2=$ somewhat disagree, $3=$ disagree, $4=$ neutral, $5=$ somewhat agree, 6 = agree, $7=$ strongly agree. The constructs in our study were measured with items adopted from previous studies utilizing already developed scales. In the research model cooperation is a dependent variable, whereas expressive ties, instrumental ties, trust, reciprocity and identification sharing function as independent variables.

\section{Team cooperation}

Team performance was measured with the adjusted scale of Baruch and Lin (2012) who adopted the measurements for team performance from Stewart and Barrick (2000). The scale proved to be reliable with Cronbach's Alpha $(a=.83)$. Both team behaviors and team outcomes make up team performance and were included in the original version of scale measuring. In our study we assessed cooperation quality and the extent to which they engage in cooperation. 


\section{Akmal Hudaykulov, Xu Hongyi \\ The effects of social capital on team performance: A study of RD departments in Uzbekistan}

\section{Social capital (trust, identification, expressive and instrumental ties, reciprocity)}

Social capital elements were assessed by adopting the scales used by Lin (2007) and Wasko and Faraj (2000).

\section{DATA COLLECTION}

Academy of Sciences in Tashkent provided emails of Uzbek scientists that participated on those projects, which made it less complicated to reach the targeted sample. The sample encompassed team members working in R\&D departments, which were employed at the time of the data collection. Total population of 7 companies active at the time of data collection were taken into consideration as a target sample of our survey. After the pilot study, the final version of the questionnaire was distributed to project participants. Data were collected from the employees of various R\&D departments and units in Uzbekistan textile industry. We disseminated the standardized self-administered questionnaire to 200 email addresses, of which some were collected by the research himself accessing public information available on the internet, and others provided by the Academy of Sciences in Tashkent. To avoid the threat of single-source bias we collected our data from two different sources, both managers and regular team members. Respondents were asked to provide demographic information as part of the questionnaire, including age, gender, job tenure, education level and their career field. Out of 200 responses, all the incomplete were filtered, leaving 170 responses that were used for statistical analysis. Subsequently, results are presented in the next section.

\section{RESULTS}

As a part of the Structural Equation Modeling (SEM) the goodness of fit was assessed, composite reliability, scalar estimates. The SEM approach involved the confirmatory approach to model specification. Additionally, normality tests were conducted and the QQ plot examination was performed showing that data was normally distributed. Reliability of the measurement tool was confirmed as all the scales exhibited sufficient Cronbach Alpha value $>0.7$ Validity was confirmed through factor analysis. After the reliability and validity conditions were satisfied further analysis on the structural model was performed in order to assess the predictive value of the research model. Correlation analysis was performed followed by the multiple regression analysis and t-test.

A Pearson product-moment correlation was run to determine the social capital relationship with cooperation. The data showed no violation of normality, linearity or homoscedasticity. There was a strong, positive correlation between cooperation and trust in co-workers $(r=.707, n=170, p<.0005)$, trust in workers and reciprocity $(r=.601, n=170, p<.0005)$, identification and trust in co-worker $(r=$ .723, $n=170, p<.0005)$, cooperation and identification $(r=.685, n=170, p<.0005)$, reciprocity and cooperation $(r=.567, n=170, p<.0005)$, identification and reciprocity $(r=.652, n=170, p<.0005)$, instrumental ties and identification $(r=.569, n=170, p<.0005)$, cooperation and instrumental ties $(r=.524, n=170, p<.0005)$, a which was statistically significant. 
Akmal Hudaykulov, Xu Hongyi

The effects of social capital on team performance: $A$ study of RD departments in Uzbekistan

\section{CORRELATIONS}

\begin{tabular}{|c|c|c|c|c|c|c|c|c|c|}
\hline \multicolumn{10}{|c|}{ Correlations } \\
\hline & & $\begin{array}{c}\text { Trust in } \\
\text { coworkers }\end{array}$ & $\begin{array}{c}\text { Learning } \\
\text { orientation }\end{array}$ & $\begin{array}{c}\text { Performance } \\
\text { orientation }\end{array}$ & Cooperation & Reciprocity & Identification & $\begin{array}{c}\text { Instrumental } \\
\text { ties }\end{array}$ & $\begin{array}{c}\text { Expressive } \\
\text { ties }\end{array}$ \\
\hline \multirow[t]{4}{*}{$\begin{array}{l}\text { Trust in } \\
\text { coworkers }\end{array}$} & $\begin{array}{l}\text { Pearson } \\
\text { Correlation }\end{array}$ & 1 &, $252^{* *}$ &,- 060 &, $707^{* *}$ & $601^{* *}$ & $.723^{* *}$ & $497^{* *}$ & $271^{* *}$ \\
\hline & Sig. (2-tailed) & & ,001 & 440 & .000 & .000 & .000 &, 000 & .000 \\
\hline & $\mathrm{N}$ & 170 & 170 & 170 & 170 & 170 & 170 & 170 & 170 \\
\hline & $\mathrm{N}$ & 170 & 170 & 170 & 170 & 170 & 170 & 170 & 170 \\
\hline \multirow[t]{3}{*}{ Cooperation } & $\begin{array}{l}\text { Pearson } \\
\text { Correlation }\end{array}$ & $2707^{* *}$ & $373^{* *}$ &,- 051 & 1 & $.567^{* *}$ & $685^{* *}$ & $.524^{* *}$ & $321^{* *}$ \\
\hline & Sig. (2-tailed) & .000 & .000 & .508 & & .000 & .000 & .000 & .000 \\
\hline & $\mathrm{N}$ & 170 & 170 & 170 & 170 & 170 & 170 & 170 & 170 \\
\hline \multirow[t]{3}{*}{ Reciprocity } & $\begin{array}{l}\text { Pearson } \\
\text { Correlation }\end{array}$ & $.601^{* *}$ & $313^{* *}$ &,- 022 & $.567^{* *}$ & 1 & $.652^{* *}$ & $461^{* *}$ & $.193^{*}$ \\
\hline & Sig. (2-tailed) & 000 &, 000 & .780 & .000 & & .000 &, 000 & .012 \\
\hline & $\mathrm{N}$ & 170 & 170 & 170 & 170 & 170 & 170 & 170 & 170 \\
\hline \multirow[t]{3}{*}{ Identification } & $\begin{array}{l}\text { Pearson } \\
\text { Correlation }\end{array}$ & $.723^{* *}$ & $367^{* *}$ &,- 042 & $.685^{* *}$ & $.652^{* *}$ & 1 & $.569^{* *}$ & $374^{* *}$ \\
\hline & Sig. (2-tailed) & .000 &, 000 & .590 & .000 & .000 & & .000 & .000 \\
\hline & $\mathrm{N}$ & 170 & 170 & 170 & 170 & 170 & 170 & 170 & 170 \\
\hline \multirow[t]{3}{*}{$\begin{array}{l}\text { Instrumental } \\
\text { ties }\end{array}$} & $\begin{array}{l}\text { Pearson } \\
\text { Correlation }\end{array}$ & $497^{* *}$ & $331^{* *}$ &,- 075 & $.524^{* *}$ & $461^{* *}$ & $.569^{* *}$ & 1 & $446^{* *}$ \\
\hline & Sig. (2-tailed) & 000 & 000 & 329 & 000 & 000 & .000 & & .000 \\
\hline & $\mathrm{N}$ & 170 & 170 & 170 & 170 & 170 & 170 & 170 & 170 \\
\hline \multirow[t]{3}{*}{$\begin{array}{l}\text { Expressive } \\
\text { ties }\end{array}$} & $\begin{array}{l}\text { Pearson } \\
\text { Correlation }\end{array}$ & $271^{* *}$ & .142 & .017 & $321^{* *}$ & $.193^{*}$ & $374^{* *}$ & $446^{* *}$ & 1 \\
\hline & Sig. (2-tailed) & 000 & .066 & 821 & 000 & 012 & .000 &, 000 & \\
\hline & $\mathrm{N}$ & 170 & 170 & 170 & 170 & 170 & 170 & 170 & 170 \\
\hline
\end{tabular}

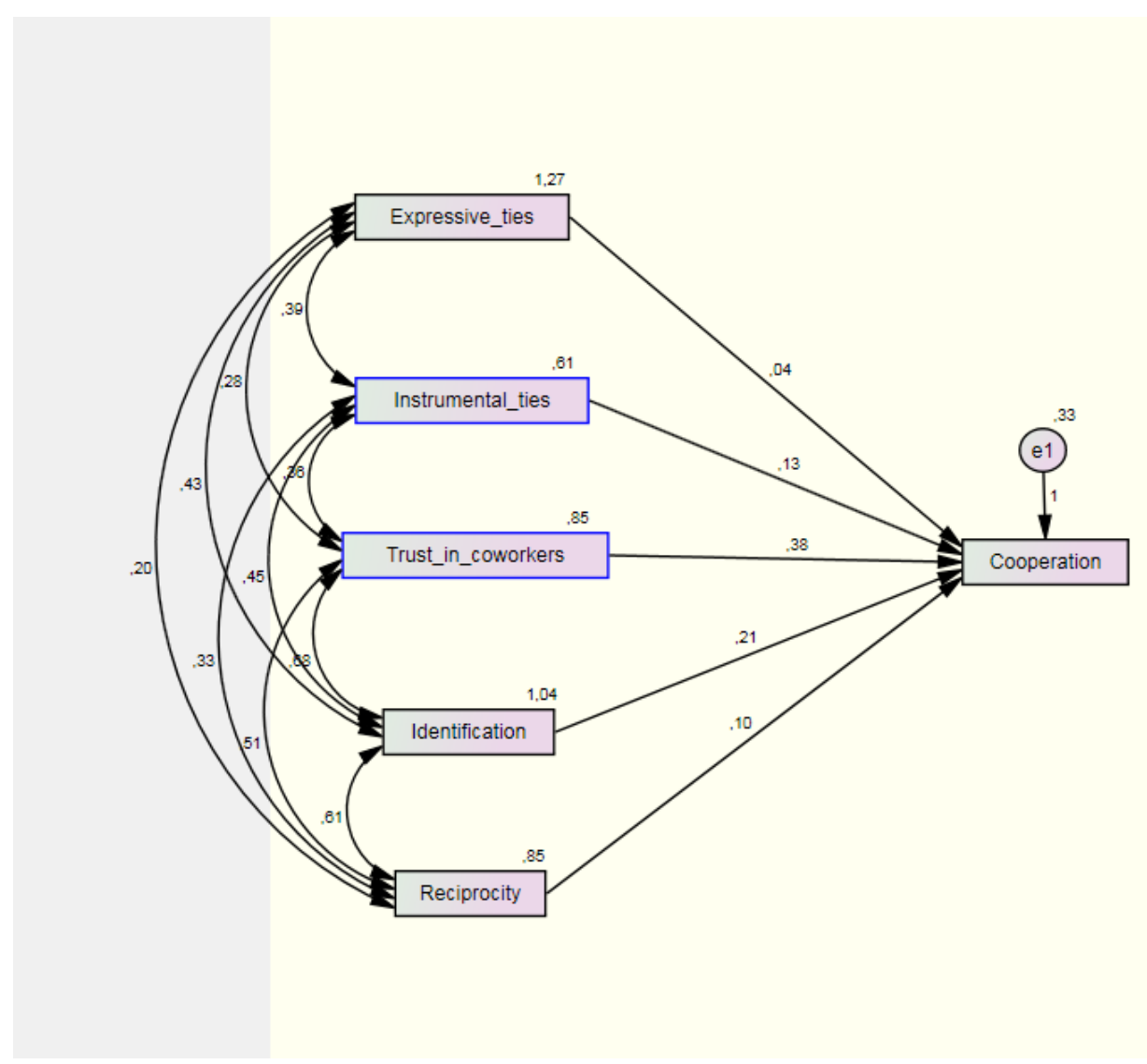

Figure 5-1 Structural Model results

From above figure 5-1 we can conclude that the resulted SEM model from Amos 21.0 was described graphically. The model analysis was conducted to determine the causal relationship among expressive ties, instrumental ties, trust in co-workers, identification, reciprocity and cooperation. Figure 5-1 showed the results of model tests. 


\section{Akmal Hudaykulov, Xu Hongyi \\ The effects of social capital on team performance: $A$ study of RD departments in Uzbekistan}

The structural model reflecting the assumed linear, causal relationships among the constructs was tested with the data collected from the validated measures. The model fit indices were within the accepted thresholds: $\mathrm{CMIN} / \mathrm{DF}=32.95, \mathrm{GFI}=.42, \mathrm{CFI}=.00, \mathrm{TLI}=.00$ and $\mathrm{RMSEA}=.43$. The estimate and the standardized regression coefficients were explained in order to determine the validity of the hypothesized paths. The statistical significance of all structural parameter estimates are illustrated in Figure 5-1

Table Regression Weight

Standardized estimates are used when comparing direct effects on a given endogenous variable in a

\begin{tabular}{|l|l|l|l|l|l|l|l|}
\hline & & & Estimate & S.E. & C.R. & P & Label \\
\hline Cooperation & $<---$ & Expressive_ties &, 040 &, 045 &, 885 &, 376 \\
\hline Cooperation & $<---$ & Instrumental_ties &, 134 &, 074 & 1,808 &, 071 \\
\hline Cooperation & $<---$ & Trust_in_coworkers &, 382 &, 072 & 5,281 & $* * *$ \\
\hline Cooperation & $<---$ & Identification &, 215 &, 073 & 2,955 &, 003 \\
\hline Cooperation & $<---$ & Reciprocity &, 104 &, 066 & 1,566 &, 117 \\
& & & & & &
\end{tabular}

single group study. Table 5-5 shows that the critical ratio (CR) value is greater than 1.96 for a regression weight, and that the path was significant at the .05 level or better. In the standardized estimate column, three asterisks $(* * *)$ indicate significance smaller than .001 ; two asterisks indicate significance at the

level of .01. All paths in the hypothesized model are significant at the level of .001, .01, and .05, accordingly. Note: $* \mathrm{p}<.05, * * \mathrm{p}<.01, * * * \mathrm{p}<.001$

The predictors of cognitive social capital showed a significant amount of variance in the full structural model; the path flowing from trust in co-workers to cooperation (standardized estimate .07, C.R. = 5.28, $\mathrm{p}=.001$ ); the path flowing from cognitive to relational social capital(standardized estimate .47, C.R. = 4.18, $\mathrm{p} \mathrm{<.001);} \mathrm{the} \mathrm{path} \mathrm{flowing} \mathrm{from} \mathrm{Identification} \mathrm{to} \mathrm{cooperation} \mathrm{(standardized} \mathrm{estimate} \mathrm{.07,} \mathrm{C.R.=}$ 2.95, $p=.003$ ); and the path flowing from the instrumental ties to cooperation (standardized estimate .07$, C.R. $=1.80, p=.071)$.

However, the path flowing from expressive ties to cooperation (standardized estimate .04, C.R. = 0.88, $\mathrm{p}=.376$ ); the path flowing from reciprocity to cooperation (standardized estimate $.06, \mathrm{C} . \mathrm{R} .=.56$, $\mathrm{p}=.117$ were not significant.

Table Covariances

\begin{tabular}{|l|l|l|l|l|l|l|l|}
\hline & & & Estimate & S.E. & C.R. & P & Label \\
\hline Expressive_ties & $<-->$ & Reciprocity &, 200 &, 081 & 2,461 &, 014 \\
\hline Reciprocity & $<-->$ & Instrumental_ties &, 330 &, 061 & 5,440 & $* * *$ \\
\hline Reciprocity & $<-->$ & Trust_in_coworkers &, 509 &, 076 & 6,696 & $* * *$ \\
\hline Reciprocity & $<-->$ & Identification &, 611 &, 086 & 7,097 & $* * *$ \\
\hline Trust_in_coworkers & $<-->$ & Identification &, 679 &, 089 & 7,615 & $* * *$ \\
\hline Instrumental_ties & $<-->$ & Identification &, 453 &, 070 & 6,433 & $* * *$ \\
\hline Expressive_ties & $<-->$ & Identification &, 430 &, 094 & 4,549 & $* * *$ \\
\hline Instrumental_ties & $<-->$ & Trust_in_coworkers &, 356 &, 062 & 5,783 & $* * *$ \\
\hline Expressive_ties & $<-->$ & Trust_in_coworkers &, 282 &, 083 & 3,406 & $* * *$ \\
\hline Expressive_ties & $<-->$ & Instrumental_ties &, 392 &, 074 & 5,292 & $* * *$ \\
\hline
\end{tabular}

In these results, the covariance among variables as shown in the Table Covariances, expressive ties and reciprocity (standardized estimate $.020, C . R .=2.46, p=.014$ ), reciprocity and instrumental ties (standardized estimate .33, C.R. $=5.44, \mathrm{p}<.001$ ), trust in co-workers and reciprocity standardized estimate $.51, \mathrm{C} . \mathrm{R} .=6.97, \mathrm{p}<.001$ ), identification and reciprocity (standardized estimate .61, C.R.= 
7.09, $\mathrm{p}<.001$ ), trust in co-workers and identification (standardized estimate $.68, \mathrm{C} . \mathrm{R} .=7.61, \mathrm{p}<.001$ ), instrumental ties and identification (standardized estimate $.45, \mathrm{C} . \mathrm{R} .=6.43, \mathrm{p}<.001$ ), identification and expressive ties (standardized estimate .43, C.R. $=4.55, \mathrm{p}<.001$ ), instrumental ties and trust in coworkers (standardized estimate $.35, \mathrm{C} . \mathrm{R} .=5.78, \mathrm{p}<.001$ ), expressive ties and trust in co-workers (standardized estimate $.28, \mathrm{C} . \mathrm{R} .=3.40, \mathrm{p}<.001$ ), instrumental ties and expressive ties (standardized estimate $.39, C . R .=5.29, p<.001$ ) indicate positive correlations and they are accepted as significant.

Table Variances: (Group number 1 - Default model)

\begin{tabular}{|l|l|l|l|l|l|}
\hline & Estimate & S.E. & C.R. & P & Label \\
\hline Expressive_ties & 1,271 &, 138 & 9,192 & $* * *$ & \\
\hline Reciprocity &, 845 &, 092 & 9,192 & $* * *$ \\
\hline Instrumental_ties &, 607 &, 066 & 9,192 & $* * *$ \\
\hline Trust_in_coworkers &, 848 &, 092 & 9,192 & $* * *$ \\
\hline Identification & 1,042 &, 113 & 9,192 & $* * *$ & \\
\hline e1 &, 331 &, 036 & 9,192 & $* * *$ & \\
\hline
\end{tabular}

Trust and identification were identified as significant independent predictors during the model selection with other three factors; reciprocity, expressive ties and instrumental ties, exhibiting a value of maximum adjusted $\mathrm{R} * 2=0,572$. The predictive power of the model was characterized and assessed using the $\mathrm{R} 2$ value $(0,585)$.

Model Summary

\begin{tabular}{|c|c|c|c|c|}
\hline Model & $\mathbf{R}$ & R Square & $\begin{array}{l}\text { Adjusted R } \\
\text { Square }\end{array}$ & $\begin{array}{l}\text { Std. Error of } \\
\text { the Estimate }\end{array}$ \\
\hline 1 & $765^{a}$ & 585 &, 572 & ,58598 \\
\hline
\end{tabular}

ANOVA $^{\mathrm{a}}$

\begin{tabular}{|c|c|c|c|c|c|}
\hline Model & $\begin{array}{l}\text { Sum of } \\
\text { Squares }\end{array}$ & Df & Mean Square & $\mathbf{F}$ & Sig. \\
\hline $\begin{array}{c}\text { Regression } \\
\text { Residual } \\
\text { Total }\end{array}$ & $\begin{array}{r}79,267 \\
56,314 \\
135,580\end{array}$ & $\begin{array}{c}5 \\
164 \\
169\end{array}$ & $\begin{array}{r}15,853 \\
, 343\end{array}$ & 46,169 &, $000^{\mathrm{b}}$ \\
\hline
\end{tabular}

a. Dependent Variable: Cooperation

b. Predictors: (Constant), Expressive_ties, Reciprocity, Instrumental_ties, Trust_in_coworkers, Identification 


\section{Akmal Hudaykulov, Xu Hongyi \\ The effects of social capital on team performance: A study of RD departments in Uzbekistan}

Finally t-test was performed to test the hypothesis. In the process of hypotheses testing first null hypothesis is defined as $\mathrm{HO}$ : = hypothesizing opposite of the posited relationship. For the mean regression coefficients, with $95 \%$ confidence null hypothesis can be rejected at $p<0.005$.

Therefore, we concluded that the following hypotheses were accepted:

H2 Trust has a positive impact on cooperation $(\beta=0,382$, sig. 0.000$)$

H3 Identification has positive impact on cooperation $(\beta=0,215$, sig. 0.004$)$

On the other hand, these hypotheses were rejected:

H1a Expressive ties have a positive impact on cooperation $(\beta=0,040$, sig. 0.384$)$

H1b Instrumental ties have a positive impact on cooperation $(\beta=0,134$, sig. 0.077$)$

H4 Reciprocity has a positive impact on cooperation $(\beta=0,104$, sig. 0.125$)$

\section{DISCUSSION AND CONCLUSION}

Our research results suggest that trust and identification are the most significant predictors of cooperation between team members. When team members within R\&D departments trust each other they will engage more in collaboration. Trust enables the creation of trust-based relationships which are a foundation for effective cooperation. This finding corresponds with the prior literature which states that trust leads to team cooperation (Axelrod, 1984; Ekelund, 2002; Garbarino and Johnson, 1999; Morgan and Hunt, 1994; Mukherjee and Nath, 2003; Rodriguez and Wilson, 2002; Varamaki, 2001; Wetzels et al., 1998; Wong and Sohal, 2002; Ylimaz and Hunt, 2001). In order to facilitate cooperation and creation of social capital organizations should focus on implementing mechanisms that would enhance trust between team members. For example, one way to increase trust is through interpersonal cooperation (Morgan and Hunt, 1994). Therefore, trust leads to cooperation, and it is also affected by it. Identification is another important factor that has a positive impact on cooperation. Identification enhances the perspectives aligned to understanding, reflection, and anticipate the other party's needs and intentions, as well as create a shared basis for cooperation. Our findings are in line with the exchange theory (Cook and Emerson, 1978) which recognizes identification as having a strong relationship with team cooperation (Ko, Price, and Mueller, 1997). While, Gundlach, Achrol, and Mentzer, (1995); Mavondo and Rodrigo, (2001). Reciprocity, expressive ties, and instrumental ties, on the other hand, did not exhibit a significant relationship with cooperation. Overall, social capital is a good predictor of team members' cooperation and should therefore be a factor to which organizations pay attention to. Human resource department should create and implement initiatives aiming to enhance trust and identification between team members. Certain training and team building exercizes would serve this purpose. With this study we have achieved the aim of showing the importance of social capital to cooperation. Nevertheless, we suggest that future studies are conducted to validate our findings, given that our findings may be context specific. 


\section{Akmal Hudaykulov, Xu Hongyi \\ The effects of social capital on team performance: A study of RD departments in Uzbekistan}

\section{REFERENCES}

- Asanuma, B. (1989). Manufacturer-supplier relationships in Japan and the concept of relationspecific skill. Journal of the Japanese and international economies, 3(1), 1-30.

- Axelrod, R. (1986). An evolutionary approach to norms. American political science review, 80(04), 1095-1111.

- Badrinarayanan, V., \& Arnett, D. B. (2008). Effective virtual new product development teams: an integrated framework. Journal of Business \& Industrial Marketing, 23(4), 242-248.

- Bandura, A. (1977). Self-efficacy: toward a unifying theory of behavioral change. Psychological review, 84(2), 191.

- Barber, B. (1983). The logic and limits of trust (Vol. 96). New Brunswick, NJ: Rutgers University Press.

- Barney, J. B., \& Hansen, M. H. (1994). Trustworthiness as a source of competitive advantage. Strategic management journal, 15(S1), 175-190.

- Baruch, Y., \& Lin, C. P. (2012). All for one, one for all: Coopetition and virtual team performance. Technological Forecasting and Social Change, 79(6), 1155-1168.

- Belliveau, M. A., O'Reilly, C. A., \& Wade, J. B. (1996). Social capital at the top: Effects of social similarity and status on CEO compensation. Academy of Management Journal, 39(6), 1568-1593.

- Blau, H. (1964). The impossible theater: a manifesto. Macmillan.

- Bonner, J. M., Kim, D., \& Cavusgil, S. T. (2005). Self-perceived strategic network identity and its effects on market performance in alliance relationships.Journal of Business Research, 58(10), 1371-1380.

- Casciaro, T. (1998). Seeing things clearly: Social structure, personality, and accuracy in social network perception. Social Networks, 20(4), 331-351.

- Chung, L. H., \& Gibbons, P. T. (1997). Corporate Entrepreneurship The Roles of Ideology and Social Capital. Group \& Organization Management, 22(1), 10-30.

- Coleman, J. S. (1988). Social capital in the creation of human capital.American journal of sociology, S95-S120.

- Cook, K. S., Emerson, R. M., Gillmore, M. R., \& Yamagishi, T. (1983). The distribution of power in exchange networks: Theory and experimental results.American journal of sociology, 275-305.

- Dore, R. (1983). Goodwill and the spirit of market capitalism. British journal of Sociology, 459482.

- Fernandez, R. M., Castilla, E. J., \& Moore, P. (2000). Social capital at work: Networks and employment at a phone center. American journal of sociology, 1288-1356.

- Ferragina, E. (2010). Social capital and equality: Tocqueville's legacy: Rethinking social capital in relation with income inequalities. The Tocqueville Review/La Revue Tocqueville, 31(1), 73-98.

- Gabbay, S. M., \& Zuckerman, E. W. (1998). Social capital and opportunity in corporate R\&D: The contingent effect of contact density on mobility expectations. Social Science Research, 27(2), 189-217.

- Gabbay, S. M., \& Zuckerman, E. W. (1998). Social capital and opportunity in corporate R\&D: The contingent effect of contact density on mobility expectations. Social Science Research, 27(2), 189-217.

- Garbarino, E., \& Johnson, M. S. (1999). The different roles of satisfaction, trust, and commitment in customer relationships. the Journal of Marketing, 70-87.

- Gerlach, M. L. (1992). The Japanese corporate network: A blockmodel analysis. Administrative Science Quarterly, 105-139.

- Granovetter, M. (1983). The strength of weak ties: A network theory revisited.Sociological theory, 1(1), 201-233.

- Gundlach, G. T., Achrol, R. S., \& Mentzer, J. T. (1995). The structure of commitment in exchange. The Journal of Marketing, 78-92.

- Hargadon, A., \& Sutton, R. I. (1997). Technology brokering and innovation in a product development firm. Administrative science quarterly, 716-749.

- Helliwell, J. F., \& Putnam, R. D. (1995). Economic growth and social capital in Italy. Eastern Economic Journal, 295-307.

- Helper, S., \& Levine, D. I. (1992). Long-term supplier relations and product-market structure. Journal of Law, Economics, \& Organization, 561-581. 


\section{Akmal Hudaykulov, Xu Hongyi \\ The effects of social capital on team performance: A study of RD departments in Uzbekistan}

- Jackman, R. W., \& Miller, R. A. (1998). Social capital and politics. Annual Review of Political Science, 1(1), 47-73.

- Ko, J. W., Price, J. L., \& Mueller, C. W. (1997). Assessment of Meyer and Allen's three-component model of organizational commitment in South Korea.Journal of applied psychology, 82(6), 961.

- Kraatz, M. S. (1998). Learning by association? Interorganizational networks and adaptation to environmental change. Academy of management journal, 41(6), 621-643.

- Krackhardt, D., \& Hanson, J. R. (1993). Informal networks. Harvard business review, 71(4), 104111.

- Kumar, N., Scheer, L. K., \& Steenkamp, J. B. E. (1995). The effects of perceived interdependence on dealer attitudes. Journal of marketing research, 348-356.

- Lewis, J. P. (2004). Team-based project management. Beard Books

- Lin, N. (1999). Social networks and status attainment. Annual review of sociology, 467-487.

- Mavondo, F. T., \& Rodrigo, E. M. (2001). The effect of relationship dimensions on interpersonal and interorganizational commitment in organizations conducting business between Australia and China. Journal of Business Research, 52(2), 111-121.

- Medina-Muñoz, D., \& Garćla-Falcón, J. M. (2000). Successful relationships between hotels and agencies. Annals of Tourism Research, 27(3), 737-762.

- Mehra, A., Kilduff, M., \& Brass, D. J. (2001). The social networks of high and low self-monitors: Implications for workplace performance. Administrative science quarterly, 46(1), 121-146.

- Molm, L. D., Collett, J. L., \& Schaefer, D. R. (2007). Building solidarity through generalized exchange: A theory of Reciprocity1. American Journal of Sociology, 113(1), 205-242.

- Morgan, R. M., \& Hunt, S. D. (1994). The commitment-trust theory of relationship marketing. the journal of marketing, 20-38.

- Nahapiet, J., \& Ghoshal, S. (1998). Social capital, intellectual capital, and the organizational advantage. Academy of management review, 23(2), 242-266.

- Prashant, K., \& Harbir, S. (2009). Managing strategic alliances: what do we know now, and where do we go from here?. The Academy of Management Perspectives, 23(3), 45-62.

- Raider, H. J., \& Burt, R. S. (1996). Boundaryless careers and social capital.The boundaryless career: A new employment principle for a new organizational era, 42(2), 187-200.

- Romo, F. P., \& Schwartz, M. (1995). The structural embeddedness of business decisions: The migration of manufacturing plants in New York State, 1960 to 1985. American sociological review, 874-907.

- Rowley, T., Behrens, D., \& Krackhardt, D. (2000). Redundant governance structures: An analysis of structural and relational embeddedness in the steel and semiconductor industries. Strategic Management Journal, 21(3), 369-386.

- Shane, S., \& Cable, D. (2002). Network ties, reputation, and the financing of new ventures. Management Science, 48(3), 364-381.

- Smitka, M. (1991). Competitive ties: Subcontracting in the Japanese automotive industry. Columbia University Press.

- Stewart, G. L., \& Barrick, M. R. (2000). Team structure and performance: Assessing the mediating role of intrateam process and the moderating role of task type. Academy of management Journal, 43(2), 135-148.

- Uzzi, B. (1997). Social structure and competition in interfirm networks: The paradox of embeddedness. Administrative science quarterly, 35-67.

- Wasko, M. M., \& Faraj, S. (2005). Why should I share? Examining social capital and knowledge contribution in electronic networks of practice. MIS quarterly, 35-57.

- Wolf, A., Eklund, M., \& Soderstrom, M. (2005). Towards cooperation in industrial symbiosis: considering the importance of the human dimension. Progress in Industrial Ecology, an International Journal, 2(2), 185-199.

- Wong, A., \& Sohal, A. (2002). An examination of the relationship between trust, commitment and relationship quality. International Journal of Retail \& Distribution Management, 30(1), 34-50. 